\title{
Reconsidering Post-war Narratives of Involvement in Nazi Violence
}

\section{By Stefanie Rauch}

Abstract: While the testimonies of survivors have come to occupy an important place in the scholarship on National Socialism and the Holocaust, and their post-war reverberations, the lesser-known corpus of recordings of perpetrators in a narrow judicial sense and the wider non-persecuted German and Austrian populace continues to be under-researched and under-theorised. In this article, I will consider approaches to utilising these complex sources in light of narrative interviews with individuals who witnessed, became complicit in, facilitated, or benefitted from National Socialist violence. Drawing on a collection of recent interviews by a documentary filmmaker, I will demonstrate the importance of the context of their co-production and their socio-political and cultural embeddedness. I will develop an approach that goes beyond the divide between event and meaningfocussed uses of such sources, instead analysing them as cultural artefacts of a particular time and place. In doing so, I will identify a rise in anxiety in approaching Germans and Austrians on the side of persecutors and the appropriation of the figure of the contemporary witness or Zeitzeuge as practice, performance, discursive strategy, and subject position.

Author Details: Dr Stefanie Rauch is a Research Associate at UCL's Institute of Advanced Studies as part of the AHRC-funded, collaborative project Compromised Identities? Reflections on Perpetration and Complicity under Nazism. She is interested in questions of knowledge production, agency, representation, and identity. Her current research explores how non-persecuted Germans and Austrians negotiated having stood on the "wrong side of history," once the moral and normative parameters shifted after 1945. In her PhD in History, which she received at the University of Leicester, she focused on the reception of films about the Holocaust in Britain.

Email address: $\underline{\text { s.rauch@ucl.ac.uk }}$

Keywords: oral history; perpetrators; complicity; documentary; identity; artefacts; anxiety; Zeitzeuge 


\section{Introduction}

Lawrence Langer once addressed the lacunae of perpetrator voices in the archive, contrasting the value of survivor testimonies with the lies, deceptions, and 'transparent evasions' of the likes of Adolf Eichmann or Franz Suchomel. ${ }^{1}$ Insofar as they have been collected at all, historians have largely neglected post-war voices from the side of the persecutors. Comparably few in number yet still sizeable - several thousand, perhaps - such accounts are widely dispersed, difficult to locate, and are, where they form part of researchers' private archives or where data protection, privacy, and consent are in question, not always open for further research. ${ }^{2}$ The provenance of such accounts is varied, complex, and bound up with the processes of confronting the Nazi past since 1945. They remain under-archived, under-used, and under-theorized.

Current research working with such accounts falls into two broad categories, each of which have limitations. The first of the two strands of scholarship seeks to salvage useful historical information about the Nazi past, often focussing on accounts (especially interrogation protocols) resulting from trials and therefore especially on camp guards, face to face killers, their superiors, and higher-level functionaries. Most notably, in Collected Memories: Holocaust History and Postwar Testimony (2003), Christopher Browning examines several post-war accounts of Adolf Eichmann. He applies four tests-self-interest, vividness, possibility, and probability - to establish to what extent and which elements of Eichmann's accounts can be seen as reliable, and whether and how these can contribute to our understanding of how the so-called 'Final Solution' developed. ${ }^{3}$ There are several limits to such an approach, particularly when faced with accounts not of well-documented perpetrators, but more lowly actors, who became involved in the National Socialist project in a wide variety of ways and who later represented their participation and association in light of a changed and ever- 
changing legal, political, cultural and social landscape. Their often-patchy accounts are difficult to corroborate. Moreover, such a general approach overlooks the specific historical value of these particular sources. ${ }^{4}$ Like other ego-documents, interviews —or interrogationsdo not simply reveal an authentic self..$^{5}$ But unlike ego-documents such as diaries, letters, or memoirs, interviews are co-produced, thus revealing as much about the interviewer and the wider socio-political context as they do about the interviewee. The interaction and dynamics between them and any imagined or actual audience, their performative and pedagogical dimension along with the wider context in which the encounter takes place, are as much part of the source as is the spoken word.

These issues extend to the growing body of empirical research with perpetrators of and witnesses to mass violence in the context of genocide studies, such as in Cambodia, Rwanda, or Sierra Leone. ${ }^{6}$ While researchers increasingly reflect on the ethical and methodological implications of their ethnographic or interview-based work, ${ }^{7}$ their main analytical focus is on reconstructing motivations for participation in genocidal acts in the past, or the social processes and situations that made them possible rather than on the socio-political contexts that shape interlocutors' narratives in the present. Interviews generated in this context—often highly sensitive settings where the safety of interviewees may be at risk - are rarely open to further research.

A second strand reads interviews primarily as narratives, with regard to issues of memory, meaning, identity, and subjectivity. ${ }^{8}$ Analyses of this type are more likely to attend to the particularity of audio-visual sources, but they tend to leave unexplored how selfrepresentational strategies relate to narrator's experiences and behaviors in the past-an important prerequisite to understanding the relationship between past behaviors and attitudes, and their later representation. This strand is marked by a focus on more 'ordinary' non-Jewish, non-persecuted Germans and Austrians, or specific groups, cohorts, professions etc. Similar to 
the fieldwork conducted by genocide studies scholars, here too the resulting interviews are studied principally by the researchers who conducted them, though there are many examples of oral history interviewers depositing their recordings with archives. ${ }^{9}$ Several scholars have begun to problematize and historicize such interviews as sources, paying particular attention to the production context or their different uses by secondary researchers. What is referred to as 'secondary analysis' in German-language scholarship is still in its infancy concerning this particular corpus. 'Secondary analysis' brings the interviewer and the wider institutional and socio-political setting of interviews into focus, therefore raising a particular set of ethical and methodological questions. ${ }^{10}$ There is to date no equivalent to e.g. Langer's Holocaust Testimonies, Annette Wieviorka's The Era of the Witness, Mark Roseman's The Past in Hiding, or Jan Taubitz's Holocaust Oral History for the production or analysis of the oral and visual accounts of perpetrators or so-called 'bystanders'. ${ }^{11}$

The aims of this article are two-fold. Firstly, using the aforementioned strands as a starting point, I will consider the uses of oral and visual narratives beyond bona fide perpetrators and develop an alternative approach. This approach will balance relative historical value, an understanding of the self as constructed through narrative and interaction, with a particular focus on discourse and the wider socio-political context in which a narrative originates and within which it is embedded; in other words, as historical sources of the time in which they were created. According to Erik Erikson's work on identity and the human life cycle, throughout life, we work to integrate and synthesize biological dispositions and individual development along with social, cultural and historical contexts, in an attempt to construct a unified identity. ${ }^{12}$ By drawing on Erikson, we can account for people's need to keep intact their sense of self and identity, particularly in old age or when experiencing changes in norms and values, political and social shifts, and when under perceived or actual individual or social 'legitimising pressure.' ${ }^{13}$ In an attempt to maintain or attain ego-integrity, elderly non- 
persecuted Germans and Austrians seek to synthesize elements, which may now require justification, into their sense of self, either because outer circumstances or inner convictions have changed, or indeed both. Social psychology presumes self-interest to be the prime motivating force for people, generally understood as individual self-interest. ${ }^{14}$ But both self and self-interest are relational, social, and contingent, rather than static, unified, and authentic.

Jovan Byford usefully suggests in relation to survivor testimonies that 'the analysis of testimony as discourse might help illuminate the complex interplay between individual and collective remembering which lies at the core of testimony both as a historiographic source and a commemorative form. ${ }^{15}$ By outlining some of the underlying 'socially and culturally shared assumptions ${ }^{16}$ in encounters with the side of the persecutors, which shape these accounts, I will argue that oral and visual narratives constitute cultural and historical artefacts of the period, and the socio-political contexts and discourses in which they were co-produced. As such, they can add to the scholarship not only or primarily on the Nazi period, but also and especially on the post-war dynamics and processes which have shaped them.

Second, I will evaluate this approach in light of a set of interviews conducted by a documentary filmmaker rather than by scholars or within a judicial context. A comparison of a wider range or different types of interviews is beyond the scope of this discussion. ${ }^{17}$ Filmmakers, along with journalists, sociologists, psychologists, and institutions, have provided much of the impetus for collecting and archiving interviews specifically relating to the side of the persecutors. There is already a tradition of documentary filmmakers' edited or unedited interviews finding their way into archives for further research: The World at War (Imperial War Museum/United States Holocaust Memorial Museum (USHMM)), Claude Lanzmann's Shoah outtakes (USHMM), Eberhard Fechner's Der Prozess (Akademie der Künste/Bundesarchiv), and Guido Knopp's ubiquitous ZDF documentary interviews (zeitzeugen-portal.de). This raises questions, not least whether they constitute an appropriate 
source for historical analysis. There are both similarities and differences between judicial or police interrogations, oral histories, and interviews conducted for documentary films. ${ }^{18}$ But 'documentary interviews' certainly deserve special consideration, given their often-tendentious nature. Commercial considerations affect what is considered suitable for audience consumption, often privileging the extraordinary over the seemingly mundane. The ethical frameworks that govern academic research do not constrain filmmakers or journalists, who approach interviews with a distinct sense of moral mission. What is more, "Documentary perpetrator testimony challenges the interview mode as one of communication, information, and revelation and as a vehicle for testimonial truth." 19 The article focuses especially on the question of what is at stake for all parties involved in these interactions. In developing an alternative approach, which pays particular attention to the co-production of narratives, I will demonstrate how especially unedited interviews by a filmmaker can be a productive source for historical research.

Specifically, I will argue that firstly, narratives of violence can serve not only to preserve ego-integrity by making claims to moral agency, they can also indicate continuities of Naziera beliefs, attitudes, and justifications, which can illuminate the genesis of acts of perpetration over a sustained period of time and their later representations among more lowly actors. Secondly, interviewers operate in a climate of heightened anxiety, which affects the conduct and outcome of interviews as co-produced narratives. Third, audio-visual accounts have inherent limitations, but can nonetheless open up new avenues of enquiry, and, more importantly, constitute a source for the time and place in which they are created. And finally, interviewees draw on historically, socially, and culturally contingent self-representational strategies, built on notions of either continuity or change, to preserve ego-integrity. One such strategy is the figure, discourse, and practice of the Zeitzeuge (contemporary witness), as a morally neutral subject position, co-constructed by interviewers. 


\section{Legitimizing Violence}

To address these issues, I will discuss five case studies drawn from a collection of interviews with Germans and Austrians, who were, in the main, at least already young adults by the time Nazi Germany surrendered. Final Account: Third Reich Testimonies@UCL comprises of nearly 300 interviews with more than 250 individuals - Germans and Austrians, mostly, but also men and women from France, the Netherlands, and other countries. British documentary filmmaker Luke Holland—who directed I was a Slave Labourer (UK, 1999), A Very English Village (UK, 2005), and Good Morning Mr Hitler (UK, 1993)—conducted the interviews between 2008 and 2017 for the dual purposes of creating an archive for research and education, and with a view towards using them in a documentary film. ${ }^{20}$ We are in the unique situation where a filmmaker's archive of unedited interviews actually precedes the film. Holland passed away on 10 June 2020, only a few months before the premiere of his feature-length documentary film that was based largely on these interviews. Final Account (dir. Luke Holland, UK/US, 2020, distributed by Participant) screened at Venice Film Festival 2020 to largely positive reviews.

In an endeavour taking nearly ten years, Holland had set out to 'shoot' the killers, who pulled the trigger. He found few who would clearly fit that description. Instead, he encountered many more, who were involved in a variety of practices of exclusion and persecution. These extended from ceasing social relations to Jewish friends and acquaintances, benefitting from 'Aryanized' property, and witnessing the maltreatment of forced laborers, to providing administrative support for the resettlement of ethnic Germans to occupied territories, overseeing export and import of goods to and from occupied territories, regulating the traffic to aid the deportation of Jews, and aiding reprisals against civilian populations under the banner-or guise - of antipartisan warfare. 
Among the narrators in this collection are some 200 German and Austrian men and women, born between 1905 and 1934, who were members of Waffen-SS and Wehrmacht, secretaries in civilian firms, National Socialist and military organisations, farm workers and homemakers, among others. Some regularly spoke publicly as so-called 'contemporary witnesses' (Zeitzeugen) or published autobiographies. Holland recruited them through local gatekeepers, approached them in the streets, or sought them out in retirement homes. The majority of the 141 German men and women were born between 1918 and 1927. In other words, they are not of the generation that conceived of, initiated, and organized war and genocide in the 1930s and 1940s, but largely, in the German context, the 'first Hitler Youth generation' (born 1915-1924), which 'carried' the Third Reich because they had the 'greatest enthusiasm for and active participation in the Nazi project. ${ }^{21}$ The 62 Austrian men and women were predominantly born between 1916 and 1926 (esp. 1920-1925). Robert Knight notes that 'for most Austrians Nazi rule was overwhelmingly a wartime experience; most Austrians had not lived through the cumulative, successful, peacetime consolidation of the Nazi regime between 1933 and 1939,' which 'also suggests that a different generational dynamic was at work in post-war Austria.' To date, detailed research on this issue is still outstanding. ${ }^{22}$

The majority of the Final Account: Third Reich Testimonies@UCL interviews were conducted between 2010 and 2014, during or after the 16-month trial of John Demjanjuk, which closed in March 2011. The fact that now men in their late 80s and 90s were put on trial and convicted, may well have unsettled some of the elderly people who were interviewed, by an outsider, about their entanglement in the Third Reich. Of course, given the vast number of perpetrators, whether 'direct' or 'indirect', comparably few were ever prosecuted, let alone convicted and sentenced (and of those, few served the full sentence). More importantly, Demjanjuk's conviction for accessory to murder specifically rested on his service as a guard in an extermination camp (Sobibor), where the sole purpose was murder, and it placed 
considerable responsibility on non-German collaborators. One of the Final Account: First Reich Testimonies@UCL narrators explicitly cited the Demjanjuk trial as 'evidence' for his claims that foreign units alone were responsible for atrocities. ${ }^{23}$ The trial and its media coverage, and the discussions and conversations among family and friends it will have sparked, forms part of the interviews' broader context and may have exacted legitimising pressure on these elderly men and women, who had come of age in the 1930s and 1940s.

Of no particular prominence, they represent the 'ordinary' spectrum of German and Austrian Reich citizens, who were, in the main, not persecuted by the National Socialist regime, and who belonged to a racially defined ethnic community, or Volksgemeinschaft, whose benefits they enjoyed. Few of them fall into justiciable categories of perpetration. Some had family members who were imprisoned in concentration camps or who were killed in Aktion T4, thus complicating neat categorisations. The majority of them was situated on a wide spectrum of complicity that entailed enabling, facilitating, and benefitting from the Nazi regime and its violence alongside facets of witnessing that implicate them. This is not to say that all nonpersecuted Germans and Austrians were complicit, nor that this is a fixed and stable category. Complicity is differentiated along levels of responsibility, access to positions of power, degree of agency, and proximity to violence, and as such is highly situational.

For this article, my focus is on narratives of violence that suggest a certain degree of complicity on part of the narrator or people close to them. Such accounts bring questions around the self, self-interest, morality, and ego-integrity into sharp relief; this has implications for their use in research. Admissions to having known about, witnessed or participated in violent incidents seemingly go against self-interest. They leave the narrator vulnerable to, at worst, legal prosecution and loss of freedom (and even life depending on time and place), livelihood, or reputation if found guilty; not least result in embarrassment or constitute a threat to a person's sense of self, crafted, curated and performed over decades. And yet, a surprising 
number of people in Final Account: Third Reich Testimonies@UCL describe violent incidents, which they claim to have known about from trusted sources, witnessed, refused to partake in, been implicated in, or even perpetrated. The selected case studies reflect different levels of involvement.

Accounts in which people admit to their involvement in, or knowledge of, violence fulfil a particular function within their broader narrative and self-representation. Viewed through the lens of identity and moral integrity, we can identify a number of reasons to explain why people would tell such stories about violence and even complicity, whether or not they happened at all, or in this way. They may seek to establish credibility; deflect from other, perhaps more problematic or incriminating aspects; 'prove' the exceptional character of an incident; help differentiate between what they/we may consider illegitimate and legitimate violence; exemplify the potential or alleged risk to narrators' own lives; or for the purpose of confession and catharsis. Key to understanding such stories is their embeddedness in a wider sociopolitical context. This is true, for instance, when confronted with individuals who speak freely about violence they perpetrated or facilitated against partisans, which they often still regard as lawful and justified, while simultaneously condemning violence against Jews or other civilians which they may admit to having heard about or witnessed, and which they know is no longer acceptable. For instance, one of the interviewees in Final Account: Third Reich Testimonies@UCL compares the Wehrmacht's anti-partisan warfare to the war on terror against the Taliban to emphasize his claim that it was lawful, appropriate, and justified. ${ }^{24}$ In other words, the stories people tell about themselves adapt to changing circumstances. What is more, they are not merely or solely lies, deceptions, or evasions but become part of how people see themselves.

A poignant example is the account of H.Wn., who was born in Berlin in 1924 (int. in 2012; 88 years old). He served as an air force $\mathrm{NCO}$ in a paratrooper regiment. After the war, he 
became a history teacher and held office in the GDR's SED. He provides an account of himself as a perpetrator of violence against partisans; as a witness to violence against civilians at the hands of the Ustaša; and as a resister to violence against prisoners of war (POWs) and deserters. $^{25}$ The degree of plausibility of these individual claims aside, they indicate the different functions of narratives of violence. H.Wn. uses them in order to construct himself as a moral actor: a law-abiding, conscientious air force soldier who engaged in violence only out of a sense of duty and self-defence, and when allegedly legally sanctioned such as in the case of partisans, or in case of a written sentence. Of note is his emphasis on partisans' alleged lawlessness. He further represents himself as someone who rejects 'excessive' violence against civilians, which in his narrative is limited to sadist non-German forces. We find echoes here of Germany's penal code, which defines the crime of murder as being driven by 'base motives' and the focus on 'excess perpetrators.' This phenomenon is by no means limited to oral accounts, nor to these very recent interviews, but has been demonstrated by Jan Kiepe in relation to witness statements from members of Reserve Police Battalion 101 in the 1960s. One of them, for instance, was careful to distance himself spatially and morally from any acts of violence against Jews ('Judenaktionen') but characterizes as legitimate any action, which he labels as 'reprisal' ('Racheaktion'). ${ }^{26}$ This indicates shifting notions of legitimacy: the idea of reprisals may have been more palatable in the 1960 s than in the early $21^{\text {st }}$ century. H.Wn.'s post-war life and indeed career in the GDR would further suggest that a narrative of violence against partisans would need to preclude notions of vengeance, instead focusing on the context of combat and (guerrilla) warfare, in which killing amounts to self-defence._H.Wn. furthermore strongly identifies not only with the Socialist state, but also with the suffering that his wife's family endured under Nazism. He becomes visibly upset as he talks about the fates of one of her relatives who was deported to Majdanek and another who was sent to Buchenwald. 
That H.Wn. and other former Wehrmacht soldiers would distance themselves from the murder of civilians and POWs is hardly a surprise. The persistence of claims of the lawfulness of killing partisans provides a glimpse into the relative ease with which German soldiers would have killed alleged and actual partisans as one facet of their soldierly duties, or their 'zones of indifference. ${ }^{27}$ More importantly, this narrative would have eased living with involvement in such activities post-1945. ${ }^{28}$ What is significant is that admissions of violence against partisans and the insistence on lawfulness continue despite the two Wehrmacht exhibitions (1995-1999; revised version 2001-2004), which historians usually credit with dispelling the myth of a 'clean Wehrmacht. ${ }^{29}$ It is conceivable, however, that the persistence of the idea (or claim) that the killings were lawful is in part because of the two exhibitions. In other words, the continued notion of legitimacy surrounding the killing of partisans was helped by the controversy around the first Wehrmacht exhibition and the perceived vindication of former German Wehrmacht soldiers in the revised version. Indeed, the flood of explicit images of public hangings and mass shootings in the first exhibition brought narratives about the killings of partisans into the sphere of what could now be openly and publicly talked about, or even triggered memories of such events. The exhibition and the accompanying debates, backlash, and controversies may have therefore resulted in a process of renewed normalisation of anti-partisan warfare and its genocidal dimensions, given the extent of Wehrmacht involvement. Key of course is the insistence on, firstly, lawfulness of anti-partisan violence and, secondly, that the persons were partisans rather than civilians, let alone Jewish civilians.

H.Wn.'s example illustrates the function of narratives of violence for constructing and representing the self as a good person, provides insights into contemporary modes of thinking and behavior, and into the long post-war context of this interview, in which this account was produced.

\section{Co-Production of Narratives}


One of the most-defining features - and an often neglected aspect - of interviews is the fact that they are the outcome of an interaction. The extent to which such accounts are co-produced is exemplified in an interview Holland conducted with H.La. (int. in 2013, 91 years old), born 1922 in Hamburg. With little experience of narrating her past outside a narrow family circle, she lucidly and eagerly engages with Holland. She sits in her study next to several family photographs, including of her father, who was a member of the NSDAP and a judge at Hamburg's Hanseatisches Oberlandesgericht (Hanseatic Higher Regional Court). H.La. expresses distress at her father's responsibility for cases pertaining to naval warfare, particularly the seizing of foreign ships by the Germans; much less at his other and main remit, which was Erbgesundheit, or 'hereditary health', that is, her father decided as to who would be forcibly sterilized. Her acknowledgement — or claim — that she failed to enquire further at the time and later, seemingly embarrasses her during the encounter with Holland. At the same time, she frequently expresses her concern at her younger brother's reaction to the interview, especially if it were to find its way into a newspaper. She alludes to strained family relations stemming from her younger brother's continuing infatuation with the Nazi period. Family ties and loyalties are tested further when, towards the end of the interview, she presents a photo of another sibling, her older brother, who died in the war. She immediately apologizes for possessing the photo, because of what she calls the 'terrible uniform.' She insists that the older brother served in the Wehrmacht despite the photo that shows him wearing a uniform with death head insignia. Amidst Holland's persistent questions, H.La.'s husband, adding to a somewhat comical exchange, launches an intervention and calls a friend whom he believes sufficiently knowledgeable to verify that some Wehrmacht soldiers wore those uniforms. ${ }^{30}$

Archival research has unearthed no indication that H.La.'s older brother was in the SS, but that he indeed served in a regular Panzersturmeinheit. ${ }^{31}$ What archival records did bring to the fore, however, is the extent of her father's role in forced sterilisation. His career at the court 
owed much to the forced retirement of his Jewish predecessor, Dr Falk. ${ }^{32}$ H.La.'s father presided over the hereditary health court from its very beginning, detailing in a publication the autonomy they enjoyed in those early days in making decisions over forced sterilisations, including over issues of morality, epilepsy, and abortion. An estimated 22,000 men and women were forcibly sterilized in Hamburg between 1934 and 1945, while estimates for the Reich are around 400,000. His personnel file commends H.La.'s father as 'politically active and interested' and 'politically reliable' with a firm National Socialist 'Weltanschauung.' In the early days of the Nazi take-over, he also presided over cases of 'high treason,' and he held responsibilities in the criminal courts. He moved to Celle in 1943 after air raids destroyed the family home, now in charge of assessing the damages caused by Allied bombing. The Allies were aware of his roles in hereditary health and criminal courts. Jurists at the Court however vouched for him, claiming that he had never been a devoted Nazi, that the hereditary health courts were nothing specifically 'Nazi' and pointed out practices in Denmark, and that he had had no choice but to submit to the laws of the time. They further affirmed that he owed his career only to his skill and expertise. He was barred from returning to the court, but seemingly received a full pension and died in $1960 .{ }^{33}$

Filmed interviews open up additional avenues for research compared with audio-only interviews, where photos and objects, facial expressions, interactions between interviewer and interviewee and others are often lost to (secondary) analysis. The presence of a camera however increases the legitimising pressure on interviewees who expect an audience, thus affecting narratives and interactions. Simultaneously enjoying Holland's attention and feeling under pressure, H.La. is visibly uncomfortable in the sequence about her older brother's photograph, and suddenly has difficulty articulating herself. She nervously looks around and with a desperate sounding voice calls for her husband, a blind man born in 1942, to come to her aid. Meanwhile Holland alternately zooms in on the photograph of the brother and on H.La. or her 
husband. While the husband talks about insignia and the Waffen-SS membership of an acquaintance, the camera closes in on H.La. who remains silent, gaze lowered, her eyes seemingly teared up. The close-up is a frequent device in documentary films, demonstrating, forcing, or implying emotional responses, or indeed a lack thereof. H.La.'s discomfort in showing the photograph likely stems from the difficulty of explaining away the insignia in the presence of an outsider. Unfamiliar with the family script, Holland asks all the 'wrong' questions, and-recognizing the cinematographic potential of the 'scene', not least the visual cue of her bright red blouse calling into mind her father's judicial rope under Nazism-is rather keen to explore potential family links to the SS. But more important than whether or not H.La.'s older brother was a member of Waffen-SS or Wehrmacht is her unease at the prospect of being 'caught' by the interviewer in the middle of competing demands; her credibility is at stake. And yet, she successfully deflects from her father's complicity, her own tacit approval of forced sterilisation, and indeed any of her own attitudes and behaviors during the years 1933 to 1945 . Her older brother's possible involvement with the SS, certainly the tainting of his photographperhaps the last photo the family had received of him—with the 'terrible uniform,' weighs heavier than her father's actual involvement in ordering the forced sterilisation of thousands of men and women. The latter were recognized as a victim group only in the late 1980s indicating continuities in the perception of people with disabilities or who deviate from social norms.

Narrowly defined notions of 'self-interest' cannot fully account for the tense interaction between H.La. and Holland. Conflicting interests can impede the construction of a coherent identity and stable morality. These include competing demands or loyalties. H.La. seeks to protect her family and her own integrity. Simultaneously, she wants to be a 'good interviewee,' a 'good witness' even, for Holland whose interest in her life flatters her (at the end of the interview she expresses her surprise that her 'small, stupid recollections' could be of any 
importance), and to do so in ways that conform to present societal norms, which she is clearly well aware of. As the incident with the older brother's photograph, in particular, highlights, reconciling these demands is seemingly impossible. We further gain insights into how family narratives, secrets, and conflicts can face disruption or come to the fore through outside challenge(r)s.

Oral and visual (and written) accounts resulting from interrogations or interviews are the outcome of an encounter and constitute a negotiation, in which neither party is fully or solely in control over either process or outcome (or reception). As a result, the interviewer's selfinterest also affects the ensuing narrative — as seen in Holland's encounter with H.La. In the collection overall, the filmmaker's strong, pronounced focus on his interlocutors' involvement in the persecution of Jews and other victim groups (of 'Euthanasia', concentration camps, Soviet POWs) and his direct, sometimes leading questions are likely to have had an impact on the nature of his interlocutors' answers. His position as a foreigner, who speaks German almost without an accent, but with limited vocabulary and grammatical difficulties, may have lowered some speakers' guards, who may have also seen an opportunity to 'explain' the past and 'set the record straight.' Some likely wondered whether the filmmaker was Jewish and constructed their narratives accordingly. While he alludes to it on occasion, he does not disclose that his mother was a Jewish refugee from Austria.

We can place him in the tradition of Claude Lanzmann's style of interviewing, with a pronounced focus on detail and persistent, repetitive questioning but also in conscious opposition to Lanzmann: there are no hidden cameras here, and most speakers dutifully fill in a release form. Yet Holland somewhat minimizes his interest as filmmaker, instead emphasizing his affiliation with a UK research institution as he seeks to convince his interlocutors of his legitimate interests and credentials. The fact that Holland films the interviews with his interlocutors' consent has visual implications, such as his ability to zoom 
in on their faces, photos and artefacts, to adjust the lighting, and alter the arrangement. Compared with video interviews conducted by historians, ${ }^{34}$ Holland's interviews are visually well-crafted. Interlocutors are seated at kitchen tables, on sofas or armchairs (or next to care home beds in the case of some), close to family photographs, artwork, or other items decorating the walls. We gain a glimpse into their homes, ranging from modest to the bourgeois. They serve Holland coffee and cake. The mundanity of their surroundings is both circumstantial and strategic: juxtaposing the normality of their lives with the enormity of the interviews' subject matter. ${ }^{35}$ The unedited interviews are jarred by disruptions that point to the artifice behind them: Holland stops the camera to adjust the lighting, seating arrangement, or microphone, or lets the camera roll as he fumbles with interviewees' microphones, as care home staff or relatives enter, the telephone rings, or as Holland sharply commands interviewees not to move or muffle the microphone. The seemingly raw quality of the recordings should not obscure that here, too, an editorial and curatorial process took place, with the camera being switched on and off at various points and tapes or memory cards being changed rather than constituting a continuous stream. ${ }^{36}$ As Sue Vice argues, Lanzmann's interview techniques were conscious of their potential impact on the screen. ${ }^{37}$ In Holland's case, beyond mise-en-scène and close-ups, or shots of trembling, old hands presenting photographs and medals, he also convinces several of his interlocutors to sing Hitler Youth songs, recite poems, do a Hitler salute, or to lift or lower their shirts to show their SS blood type tattoo, ever mindful of the way this could be utilized in a future film.

Crucially, an ambiguous interview style indicates that Holland sought to ensure that he does not (appear to) give his interlocutors the last word, empathize with them, or provide them with an opportunity for unchallenged apologia and denial. He oscillates between building rapport and confrontation by asking, repeatedly, challenging or leading questions or by interrupting his interlocutors; he too faces competing demands. Indeed, at times the interviews bear more 
resemblance to interrogations than oral history interviews, exacerbated by frequent misunderstandings regarding terminology and expressions he is unfamiliar with or misinterprets. Holland operates within a particular climate: talking to people involved in the Third Reich risks accusations of identifying with them, of condoning their actions, or taking their apologia at face value. As Katherine Model highlights, 'untrustworthy interviewees' present 'an affront to documentary's tenets, and cries out to be contained by the film. The suspect testimony may be countered, explained or discredited, but rarely is it simply let be. ${ }^{38}$

This constitutes an important 'socially and culturally shared assumption' for encounters with the side of the persecutors: the spectre of providing them with a 'platform' as akin to complicity necessitates boundaries of empathy, rapport, and recognition. Interviewers engaging with this subject—be they filmmakers, journalists, or scholars-implicitly and explicitly address and perform to, and educate, an imagined or actual audience. Moreover, they relieve audiences of any potential discomfort that might accompany feelings of empathy for someone involved in Nazi persecution. As Ben Highmore notes, 'Moods and feelings don't just happen; they are produced, and most of the time their production is the result of specific work. ${ }^{39}$ Applied to the present context, Holland, the filmmaker-interviewer, acts as a mediator, performing 'mood work' through e.g. exasperated reactions, withholding of affirmation, or aggressive questioning, thus producing and releasing tension. I would describe this further as 'moral work,' as the interviewer performs, produces and validates a particular type of morality in this process. Holland is no exception: we find other examples of this in a variety of documentaries, including Ruth Beckermann's Jenseits des Krieges (Austria, 1996), Auschwitz: The Nazis and the Final Solution (UK/USA, 2005), and The Last Nazis (UK, 2009). We also find expressions of interviewers' discomfort and anxiety in audio-only recordings by professional and lay oral history interviewers, such as in Alexander von Plato's interview with an Auschwitz perpetrator or in some of the interviews conducted for an archive of Austrian life 
histories. ${ }^{40}$ Common to these efforts is a sense of moral discomfort and the keen distancing of interviewers from their interlocutors. Interviews attest to conflicting interests, between constructing a particular identity and responding in a way that is socially acceptable. This applies to interviewers, narrators, and the listener or viewer.

These issues manifest most strongly when interviewers expect an audience and where they explicitly frame their interlocutors are compromised, complicit, or even as perpetrators. Even without an audience, the increasingly important place of the Holocaust in societies of the Global North since the 1990s shape interviewers' identities to the degree that even temporary rapport and empathy with their interlocutors risks compromising their own sense of self. Holland's very personal investment and the particularities of his profession are embedded in a cultural rise in anxiety in approaching both bona fide perpetrators and the side of the persecutors more generally, since then, which is not limited to audio-visual interviews, but extends to fiction film and literature. It coincides with an increase in public Holocaust awareness and interest in issues surrounding perpetration and complicity, and the conceptual broadening of the spectrum of complicity. There has been a growing acknowledgement that perpetration and complicity encompasses more than face-to-face killers or 'desk perpetrators' as research explores the involvement of ever-wider groups of people, professions, and institutions.

Working with audio-visual accounts of individuals involved in the 'Third Reich' is fraught with ethical, methodological, and epistemological challenges. Terms such as witnessing or testimonies appear ill fitting, given their 'strong legal and religious connotations' and their ties to 'the concept of 'truth'.' 41 While of course all oral history is subjective, contingent, and bound by the workings of human memory, ${ }^{42}$ the 'moral dimension'43 of testimony poses a particular challenge when applied to the narratives of non-persecuted Germans and Austrians, some of whom were actively involved in the persecution of others, while many more benefitted 
from, facilitated, or ignored persecution. Langer is not alone in dismissing or warning of such accounts. Sybille Schmidt insists that 'perpetrator testimony requires specific hermeneutic and moral considerations', highlighting 'certain dilemmas concerning the issues of trust, truth, and authority. ${ }^{44}$ In particular, she warns of 'unintended complicity' resulting from an inappropriate engagement with this material, such as the risk of believing 'false testimony. ${ }^{45}$ The notion of true and false testimony is contentious, as is the idea of an appropriate or inappropriate engagement. Even scholars who insist on the value of 'perpetrators' accounts' distrust them from the outset. ${ }^{46}$ Dori Laub and Nanette Auerhahn even call them 'anti-testimony' by 'antiwitnesses'. ${ }^{47}$ In short, these sources are embedded in a moral discourse marked by apprehension and normativity regarding their production, use, and dissemination.

This wider discourse shapes which and how interviews are conducted, and how interviewers, researchers and other audiences approach them. The particular context and purpose of an interview or interrogation not only configures its content, it can also see shifting dynamics and concerns. This is true not only for documentary interviews. Browning notes how Eichmann's priorities would change in different phases of his post-war testimony, and how much it depended on context. For example, once confronted with Hoess's account of eventsthat Eichmann visited Auschwitz in the summer of 1941 - it was in Eichmann's interest to insist on the 'correct' chronology by dating his visit to spring 1942, rather than deny having been there at all. ${ }^{48}$ Yet what precisely Eichmann's self-interest was remains unknown. Did he harbor any hopes of a prison sentence, let alone acquittal? Did he serve his own sense of self, or did he aim his accounts at his family, or posterity? Self-interest is thus not self-evident, but highly subjective and contingent, even in the case of court and investigation records. ${ }^{49}$ The same is true for strategies of self-representation: they vary over time, place, and the resources at an individual's disposal. Self-interest need not always denote attempts at legal exculpation. It can designate moral claims relating, for instance, to the speaker, superior officers, 
subordinates, military unit, or indeed the entire army, or family members, among others. This is the case for trial testimonies as well as for interviews collected outside the interrogation and courtrooms, whether by scholars, journalists, or filmmakers. By shifting the focus from selfinterest on to identity and moral agency, we can examine what is at stake for both interviewer and narrator, and the intended or projected audience.

On some occasions, we can find archival records produced in different contexts, which aptly illustrate the extent to which all interviews and interrogations are co-produced and their contingent nature. Such a rare example is that of W.P., born 1923 in Vienna, who was interviewed twice by Holland, in 2011 and 2013, aged 88 and 90. A former paratrooper, who professes to have served in France, Holland, Montenegro (anti-partisan warfare), Italy, and North Africa, W.P. claims to have been involved in special missions, including at Monte Casino and the liberation of Mussolini. He recounts his involvement in 'securing' a village in Montenegro, as ordered by army high command, until relieved by an SS unit, acknowledging that it was common knowledge that the SS killed civilians. He was captured by the Americans in February 1944 and spent two and a half years as POW in the USA. ${ }^{50}$

During his captivity, US intelligence officers interrogated him at Fort Hunt, also, and presumably unbeknownst to W.P., bugging the cell he shared with others, a common practice among the Western Allies. ${ }^{51}$ W.P.'s file includes several interrogation protocols from June 1944 (he was then 22 years old) and partial transcripts of some of his recorded cell conversations, which mostly revolved around weaponry-indicating what the Allies considered to be pertinent in that period. A snippet from a conversation suggests that W.P. told his cellmate that he shot an Italian Communist in Rome, following a gunfight. He was of interest to the Allies as a paratrooper belonging to a battalion under the direct command of Kesselring, and as a potential source for air raid targets in his native Wiener Neustadt. ${ }^{52}$ 
Given the $65+$ years between his captivity and the interview given in old age, there are some interesting commonalities between the sources. The 'security consciousness' attested to W.P. by intelligence officers is reflected at the beginning of his 2011 interview, when he expresses concern that the interview would fall into the 'wrong hands,' be misinterpreted or taken out of context. About his captivity, he claims he was aware that the Allies overheard their conversations, implying that at least some of the German POWs suspected that the Allies were listening in or spying on them. He insists that they planted US officers in German uniforms among the POWs to glean information. He took a cautious approach to negotiate the interrogators' 'elaborate' interrogation methods.

He did not reveal to the intelligence and interrogating officers at the time- - who did suspect he was not telling 'the entire truth' and who questioned the 'honesty and reliability' of his statements - his alleged involvement in special missions, which would have been of tactical interest to the Allies. His later assertion that he cited his concern for his family as a reason to withhold information during interrogation warrants some inspection. There is no indication in the 1944 files that W.P. made particular mention of his parents and sister. Fear for their safety may well have been one of his motivations for withholding details about industry in Wiener Neustadt, which could have provided air raid targets. The presence of his wife during the interview may have shaped a narrative that constructs him as a man of virtue, (family) values, and conscience. W.P. has undoubtedly given the period considerable thought, reflecting on his then sense of pride over belonging to the elite paratroopers. He stresses the benefit of hindsight, implying that his attitudes and opinions have undergone some development since the end of the war, and he accounts for his involvement and enthusiasm by citing 'brainwashing,' which hindered independent thinking. The recent interviews still reflect that he has 'evidently been successfully indoctrinated with Nazi propaganda.' His professed rejection of Nazism is frequently at odds with utterings that betray a degree of unwitting ideological continuity. For 
instance, he describes how devastating it was to view footage of the liberated concentration camps whilst a POW in the US, dealing him a 'severe moral blow.' Subsequently, he however argues that the murder of the Jews was the regime's 'biggest mistake,' as Jews allegedly held much power in England and the USA and would make sure that Germany would not win the war, musing that this was probably the reason why America entered the war. In 1944 as in 2011 and 2013, W.P. voices anti-German and pro-Austrian sentiments. As in 1944, he remains convinced that Austrians were only 'second-class citizens,' and that they would have ultimately been Germany's 'last victims. ${ }^{53}$

The case of W.P. demonstrates the ways in which particular contexts shape and co-produce narratives. An interrogation whilst a POW at a time when the war is still going on, by enemy intelligence officers on foreign soil produces a different narrative than an interview by a British filmmaker 65 years later, where he can, for instance, talk more openly about the missions he was involved in, while also accounting for his wartime behavior and attitudes. Yet the continuities - in terms of both self-representation and ideology — also indicate a degree of stability and thus the value for historical research of narrative interviews collected decades after the events under discussion.

\section{The Limits of Knowability}

The illusion of knowability of filmed interviews, especially when they are recorded at interviewees' homes, obscures the limits of what can be known in the encounter between interviewer, narrator, and viewer. The seemingly 'natural' setting conceals the fact that here, too, a careful arrangement takes place, in turn hiding the artificial nature of the encounter. The gaps, contradictions, and unknowns in the above accounts alert us to the necessarily incomplete and inconclusive nature of these, and indeed any, interviews. Vivid narratives often appear to offer a more reliable account, with their level of detail and emotion seemingly tapping into the original experience. But they may in fact simply be better prepared, rehearsed and often-told, 
honed and solidified over time, and even incorporate elements from media representations about the past, such as films or novels. ${ }^{54}$ Indeed, Michelle Mouton and Helena PohlandtMcCormick note that research 'on memory has shown that qualities of exactness and vividness, including consistency, emotionality, and confidence in remembering, do not prove a memory to be true. ${ }^{55}$ Even the traumatic memories of Holocaust survivors are subject to change, as Mark Roseman demonstrated..$^{56}$

Incoherent and fragmented narratives, whose meaning is obscure, and which are characterized by vague and often conflicting utterings, may offer perspectives prior to their integration into established or socially acceptable narratives and life scripts. At the edge of discourse, between articulation and emotion, they are a unique product of the interaction between interlocutors. The case of H.Ro. (int. in 2011, 88 years old) who was born in Landshut in Bavaria in 1922, exemplifies this. Coming from a family of staunch Nazi supporters-his father an early member of the NSDAP and Allgemeine SS, mayor of a town in North East Bavaria, Ortsgruppenleiter, and forestry superintendent; his mother a women's leader in the local NS-Frauenschaft-H.Ro. volunteered for the Waffen-SS in 1941. According to H.Ro., following initial training with a tank unit (Panzerjägertruppe), he was transferred to a cavalry brigade in Lublin, where he stayed until the winter of 1941/42, until he was assigned, as a gunner, to a tank unit which was formed in Italy. After a few months, he was sent to 'Russia' in the autumn of 1942. H.Ro. insists that his unit saw little action. At this point, Holland (LH) asks him whether they had much contact to and relations with the Russian civilian population. The following is a translation and transcript of the ensuing exchange; the language intentionally left unpolished to intimate the original German utterings:

H.Ro.: Mostly no. Mostly no, as, because tanks were always allocated to different houses, together with the occupying forces <gestures in one direction>, where they 
were also able to sleep. $I$ <points at himself> had little to do with the civilian population and principally nothing unpleasant <shakes his head>. We talked with them with hands and feet, but that it would have come to an altercation, never. Never <shakes his head>. <Pause of several seconds during which he looks down and fumbles with his shirt>. Well <moves his head to one side> on-, once it was so, we drove with a truck and it went to some larger locality, we stopped there, and then civilians invited us if we wanted something to eat or drink. And then the following happened to me. As a young man of course I also drank, and the people, the civilians, it was Jews in this case $<$ grimaces $>$, it was a Jewish locality, that's probably why we went there $<$ moves his head to one side and back>, I had, after several glasses of vodka, I was out <LH laughs briefly>, and the Kameraden said, 'go up into your truck, you're drunk,' and that was resented, the leadership resented our company for that of course, that some soldiers received so much alcohol there, and so it is possible <looks down> that there were altercations ['Zusammenstöße']. <speaks quickly:> But otherwise there was nothing. LH: What do you mean by altercations? What happened there? [...] H.Ro.: Well, in that locality, like, that they had to come out of the houses <gestures away from himself> and, and then <lifts shoulders>, well yes, and I was then already completely drunk < lifts both hands to his head $>$, I don't know that anymore, all that happened there. There probably were some slaps in the face ['Ohrfeigen'], that's how I mean it, right.

LH: [...] How were the Jews involved in this, where did the Jews in this story come from?

H.Ro.: Well, the Jews, it was their houses. I know only one thing, that in the house where I was made drunk, that this was a Jew's house ['Judenhaus']. And then I was out. Yes and I believe the Kameraden then <grimaces, moves head from side to side> 
picked an argument probably, but I don't know that anymore <moves hand away from himself, then places hand on his shirt collar, moving it away from his neck, scratching his neck>, I was already asleep then.

LH: You mean there was trouble with the Jewish family, because you received alcohol? H.Ro.: Yes, there was trouble.

LH: But for the Jews there was then problems, did I understand that right, because they gave you alcohol?

H.Ro.: Yes, to everyone really, they gave to everyone [...] but I was small and inexperienced and after one glass vodka or two or three I was already -.

LH: Were there rules, were you permitted to have this contact with civilians? H.Ro.: Of course [...].

Holland, seemingly taken unawares by this confession-possibly exacerbated by H.Ro.'s Bavarian dialect and the general unintelligibility of the narrative-, does not enquire much further subsequently and the conversation moves on to partisans and prisoners of war, as H.Ro. regains some control over his narrative. In the remainder of his interview, H.Ro. declares his continued sense of pride for having been a member of the Waffen-SS. He denies the murder of six million Jews, and any knowledge about concentration camps. After the war, following American captivity and studying agriculture, he became a civil servant in Bavaria. His children know-and keep quiet-about the fact that he was in the Waffen-SS, instead claiming he served only in the Wehrmacht. ${ }^{57}$

In this short sequence, we observe H.Ro.'s attempt to absolve himself of responsibility, even full consciousness, as he realizes what he may be volunteering about his role in the Holocaust. In itself incoherent, full of contradictions and overall making little sense, the snippet illuminates Waffen-SS activity, involvement and self-understanding, how narratives are 
challenged, and justifications formed and negotiated in the context of conversation. Here, we also see how his interest shifts from answering the interviewer's question to distancing himself from the situation.

The different registers of the story make it difficult to follow: there is the overall incoherence of the story; its being out of place and time; the focus on alcohol rather than the fate of the Jews in this village; the narrator's volunteering of this information; and the interviewer's surprise, confusion, and subsequent failure to probe further. The sequence alludes to the incident's unusual qualities: perhaps it was the heavy drinking (somewhat unlikely given the role alcohol played especially in the East), or the physical altercations that were unusual, as Jews ought to be rounded up or killed in a more 'orderly' fashion. The 'trouble' H.Ro. hints at could refer to him and his Kameraden, or the locality's Jews. The consequences remain unknown. For H.Ro., his embarrassment is arguably not linked to his involvement in this raid, whose Jewish targets are mentioned only in passing and as a matter of fact ('it was a Jewish locality, that's probably why we went there') as though this was nothing out of the ordinary-although his grimacing betrays some discomfort about this aspect of the story at the point of disclosure- but to his own behavior as untoward for a member of the Waffen-SS.

His body language and facial expressions in the sequence are of note, as is the language: He is generally capable of speaking full and coherent sentences. This excerpt therefore stands out, also for his difficulties remembering details, which again is unusual for him as a narrator. His gesticulating also becomes more pronounced when he discusses difficult subjects such as this incident or his father's NSDAP membership. In particular, his gesture of pulling his shirt collar away from his neck may indicate discomfort, of 'getting hot under the collar'. His grimacing, head movements, and gestures could point at evasiveness while having revealed more than intended. Nicholas Chare notes the 'body may be inscribed by specific events, possibly chronicling an individual's past experiences by way of styles of gesture. ${ }^{58}$ Yet Model 
points out how in documentary interviews, we 'are especially driven to look to the body, to voice, intonations, affect, gestures when we suspect the interviewee may be hiding something. ${ }^{59}$ In other words, the documentary form privileges embodied knowledge. This is true also for unedited interviews that tend to offer more nuance and complexity.

Does the interaction between H.Ro. and Holland constitute a 'boundary crossing' where the continuity is broken and where we catch 'a glimpse of what the experience might have been like before retrospective reinterpretation altered it,' as Mouton argues? ${ }^{60}$ Franka Maubach cautions against problematic notions of a somehow untouched memory, which can be unearthed through interviews in exactly the way in which it was experienced. ${ }^{61}$ Rather, we can read it as what Lutz Niethammer calls a 'change of memory tracks. ${ }^{62}$ H.Ro.'s practiced narrative of his military training and service is disrupted (somewhat unwittingly) by the interviewer's question about relations with the civilian population. The response to this question shifts the 'memory track' onto more unfamiliar terrain, challenging his general narrative. ${ }^{63}$ Given the importance of his belonging to the SS and his notion of SS values for his sense of self, for H.Ro. the preservation of his sense of pride and honour, his reputation and that of his family is at stake. The dissonance between taking pride in yet hiding his SS past from people outside his family suggests a degree of awareness of potential repercussions resulting from his past and certainly of a changed moral landscape. There is a conflict here in the discord between H.R.'s prior Waffen-SS identity and his present sense of self, which recognizes this, in part, as problematic, at least in his encounter with the interviewer. The remainder of the interview then reads as an attempt to rehabilitate his story and identity. The sequence's fragmented qualities and different registers could further hint at this story constituting an amalgamation of a range of similar incidents into one.

The difficulty of historically corroborating an account where largely unknown figures and little-known events are involved, and where the defining feature is the-often deliberate- 
absence of details regarding geography, temporality, and personnel comes into sharp focus when we work with accounts such as H.Ro.'s. Yet more articulate, coherent and detailed accounts are not without pitfalls of their own and bring into view the constructed nature of narrating and writing history. The following example of different versions of the same, vivid story indicates the many iterations a story can undergo over time and especially over frequent retelling. Holland interviewed K.R., born in 1922 in Berlin, twice by Holland, in 2012 (aged 90) and again in $2013 .{ }^{64}$ In 2006, German high school students interviewed K.R. for a website hosting excerpts from 'contemporary witness' interviews. ${ }^{65}$ He narrates the same incident in all three interviews, which he claims occurred near Rovno, Ukraine, in the Pripyat marshes. The basic components of this narration are as follows: In his function as private in an army medical corps (Sanitätsgefreiter) and along with two other army medical privates and the assistant doctor, he witnessed an anti-partisan Aktion during winter at close range. The four of them watched as a village suspected of harboring and aiding partisans was burned to the ground and all villagers were killed. The assistant doctor was deeply distressed and K.R. and the other two medical privates had to calm him down.

Between 2006, 2012 and 2013, significant details changed, including the year (1942 in the 2006 version, 1943/44 in the 2012 account, September 1942 in the 2013 retelling), how close they were to this attack and how many people were killed, how he came to be there, and the personnel involved in the incident. He provides no figures in 2006, but claims that they were somehow 'hovering' above this Aktion ('wir schwebten darüber'). The inhabitants of the village were mostly women and children, and some elderly men. In the 2012 account, K.R. and his three Kameraden were 100 meters away, with 500 villagers killed. In 2013, he speaks of fifteen houses with 4-5 residents in each, i.e. a much smaller population, and a distance of 500 meters. In 2006, he situates and embeds this incident within a prolonged anti-partisan deployment (Partisaneneinsatz) with an armed response force (Alarmeinheit) consisting of SS, 
Wehrmacht infantry, Hungarian SS cavalry, and Police. Six years on, he claims the incident, lasting from 4pm until midnight, was a one-off; and the personnel involved in searching the village for weapons and ammunition is now strictly Hungarian, an SS cavalry unit. In 2013, he refers to the units involved as 'primarily' Hungarian but also including German SS and cavalry. In 2006, he recounts that no ammunition was found, but that some later blew up in the fire, which he calls the only 'positive' aspect, implying that, ultimately, the massacre was justified. In 2012 and 2013, he emphasizes that it was only alleged that ammunition was found and blew up in the fire.

Corroborating this account-the timing, location, and claims around the involved personnel— proves difficult. An alleged tram ride through the Krakow ghetto (told in order to bolster his argument that they were lied to by the Nazi leadership and to contrast the good relations they had with Ukrainian civilians with the ghetto conditions) en route to Rovno suggests that the timing is likely 1942/1943, i.e. before the liquidation of the ghetto mid-March 1943. If we believe his elaboration on his remaining war service, which included six months in Paris and nearly two years in Athens until the retreat from late 1944 onwards, this would actually place the massacre in the winter of $1941 / 42$. While K.R. believes or purports that the massacre was carried out in the Pripyat region around Chernobyl-around 350km East of Rovno - it is perhaps more likely that it occurred in the Pinsk marshes c. $200 \mathrm{~km}$ north of Rovno. To a degree, 'Pripyat marshes' may simply serve as a catch-all for a vast area, which was never fully conquered by the Germans, marked by swamps and marshland and encompassing both Ukrainian and Byelorussian territory, thus rendering attempts to corroborate and locate this account largely futile, especially given the pervasive violence German army, SS, police, and their allies enacted in this region.

While there was no Hungarian SS unit prior to 1944, Hungarian units were under German army command in the area of Army Group South. K.R.'s singling out of Hungarian forces may 
speak to the documented tensions between German army command and Hungarian forces in the area of Army Group South. ${ }^{66}$ It certainly if not primarily serves to create distance between himself and the German forces on the one hand, and the Hungarians hunting down villagers on the other. The exact nature of the massacre - whether directed against real, suspected, or alleged partisans and their helpers or against Jews under the guise of anti-guerrilla warfarecannot be established. ${ }^{67}$

What is significant is that all three versions were vividly detailed, told seemingly against self-interest - if narrowly defined—, and, while in light of other research not equally probable or possible, still strike a historical chord. Yet these features do not necessarily make any of the versions more reliable, nor are they to be dismissed out of hand and be reduced to narrative. We simply cannot be sure which version, if any of them, is closer to what actually happened, or why the story changed. The discrepancies may well stem from the fact that K.R., like H.Ro., is amalgamating what could be multiple incidents into a single one. Exceptionality can serve as defence strategy: unprepared for this one-off incident, they could take no other action, and he thus bears no responsibility for what happened.

This example alerts us to the fluidity of narrative self-representation and that we must take a cautious approach even when faced with a willing narrator disclosing his close proximity to violence, through a vivid and compelling account. Ultimately, these accounts have inherent limits, including uncertainty, ambiguity, and unknowability. An account like this can provide an impetus to conduct further research on anti-partisan attacks and massacres in Ukraine and elsewhere. The involvement of army medical personnel highlights a neglected sub-group and their day-to-day involvement, not only in tending to wounded soldiers, but also to provide 'assistance' during acts and indeed campaigns of violence. Many of them would have embarked on medical careers after the war, such as K.R. who became a dentist.

\section{Interviews as Artefacts: Situating the Zeitzeuge}


Rather than consider such interviews primarily as sources about the Nazi period, or as biographical, narrative sources, I propose to examine them as cultural artefacts of a particular period, reflecting and shaping the wider discourse about the Third Reich. One of these is the anxiety in approaching the voices of people who were involved in Nazi violence, as argued above. A second aspect concerns the contingent and co-constructed way in which the speakers in these accounts negotiate their past. Interviews can pose a fundamental challenge to attaining or preserving ego-integrity and for recognition as moral actors. Interviewers have other goals, such as unearthing new facts or, especially in the case of filmmakers, eliciting moral responses suggesting a sense of remorse or admission of guilt and responsibility, or lack thereof. Within this framework, narrators seek to construct ego-integrity, while adapting to the changing circumstances.

The strategies narrators within this collection utilized for constructing ego-integrity fall into two broad categories, emphasising either continuity or change. Continuity strategies appear to be more common. They help construct a sense of stability between people's pre- and post-1945 selves, such as seen in H.Wn.'s case. Many still defend or maintain 'positive aspects' of the regime and the 'good years' (i.e. either pre-1939 or pre-1941/1942/43) thus separating between legitimate good memories and values and criminal aspects of the regime from which they distance themselves. Others insist that they kept their (inner or outer) distance to Nazism throughout, such as K.R., who simultaneously claims limited agency. A smaller group continues to reject notions of the regime and its institutions as criminal and is engaged in revisionist or relativist rhetoric and even Holocaust denial, such as H.Ro.

Others build their ego-integrity on a sense of change and transformation. They positively re-assert their identities by critically reflecting on their role and by building on their rejection of the Nazi regime and ideology. We can consider such strategies as an expression of the change in norms and values since 1945, and the success of the notion of having 'mastered' the 
past. They signify that the narrators are, at the very least, aware that these have shifted and, at most, have adopted them to the extent that they can no longer accept that they once thought or acted differently. It may well be in an individual's self-interest to express regret or shame over past behaviors, as an act of reaffirming their morality, especially as they reach old age ${ }^{68}$ This may be what Wulf Kansteiner calls a 'reformed bystander.' 69 This can take the form of narratively constructing gradual or sudden disillusionment with the Nazi regime either before or shortly after the end of the war, such as W.P.; and conscious self-representations as having transformed since 1945, upon which a positive identity is built or re-asserted. On occasion, we find a sense of unease, indicating that different aspects have not yet been reconciled, as in the case of H.La., and where ego-integrity is impeded; predominantly in relation to admissions of what may constitute moral lapses rather than indictable actions. Further research is needed to ascertain why, when, and how different strategies are adopted, and by whom. Narratives of involvement in violence can be incorporated into either type.

Within both change and continuity strategies, the figure of the Zeitzeuge plays an important role. To exemplify this, I will return to K.R., in order to demonstrate how these interviews can provide insights into the ways in which the Nazi past has been confronted after 1945. The three interviews discussed above were not the only occasions on which he told the story about the massacre. As a registered Zeitzeuge with a local Zeitzeugenbörse, he would have repeated it on many occasions. In the 2012 interview, he refers to a talk he gave at Humboldt University in Berlin, and where an audience member 'confirmed' his narrative by claiming that the Hungarians were especially brutal. ${ }^{70}$ Over the course of six years, K.R.'s retelling of the story became increasingly distant and conscious of the fact that the killings cannot be justified, ammunitions or not. His insistence in his role as witness rather than an actor in this Aktion comes despite the fact that his presence was required to provide medical assistance in case any of the SS, Wehrmacht and Police units were injured in the process. Moreover, his presence as 
a medical private also provided moral support to the participating units, and contributed to the normalisation of the violence unleashed on civilians. K.R. even took it upon himself to calm his superior, the assistant doctor, who was gravely distressed at the scenes. In 2013, asked by Holland in somewhat clumsy German (perhaps consciously so, following Lanzmann's example ${ }^{71}$ ) how he came to be 'Mitglied dieser Aktion'—a 'member' or 'participant' in this action or campaign - K.R. firmly rejects Holland's suggestion that he was involved in the massacre by declaring: 'We were not part of it. We were standing on the side lines as principal witnesses.' ('Mitglied waren wir nicht. Sondern wir standen als Kronzeugen am Rande des Ganzen.') The wider cultural and socio-political context and discourse here intersects with representations of the self: Speaking in the first person plural, K.R. assimilates and appropriates the cultural identity of acting as a Zeitzeuge into the ways in which he represents and regards himself. In other words, the trope becomes part of an interpretive resource or repertoire, which he can tap into and, in his public and educational work, enact or perform. This helps explain why he would tell this story at all, and do so repeatedly, despite the fact that it implicates him in a massacre of elderly men, women, and children. Asked by Holland in 2013 about his own impressions at the time, K.R. relates to Holland that he then thought that what happened was 'horrible' but 'somehow had to be.' We gain a glimpse of wartime rationales and the extent to which rank-and-file soldiers had ingested them. K.R.'s uttering reflects notions of persevering with ruthless and merciless acts despite personal feelings. ${ }^{72}$ In the present, he perseveres as a Zeitzeuge out of a sense of civic duty even though the retelling of the incident seems to cause him some distress and discomfort, visually underlined by a twitching eye, repeated throat clearing, and what may be welled up eyes, zoomed in on occasion by Holland in close-ups. His service as a Zeitzeuge seemingly immunizes him from any accusations; the fact that he volunteers these stories puts him above any suspicion. As a 'principal witness,' K.R. bears no responsibility for what happened, only for sharing what he witnessed in the present. In the 
original meaning of the term, a Kronzeuge is someone who testifies against others in the hope of or following reassurance or a deal that they go free or receive a milder sentence themselves, despite their own involvement in the crime; unwittingly a much more apt term than Zeitzeuge. However surprising some of the above admissions of what amounts to different degrees of complicity may seem, few people actually perceive their involvement as such, and thus do not fear any repercussions arising from their accounts. Meanwhile, the success of the figure and idea of the Zeitzeuge, especially coupled with Germany's discourses of mastering the past and civic courage, allows narrators to portray and see themselves as mere 'witnesses' to the past, doing their bit for remembrance and education. ${ }^{73}$ Interviews with such implicated or compromised witnesses are thus marked by a tension of testifying to the times while simultaneously creating distance; of being there but not involved. Since its emergence, the figure of the Zeitzeuge has expanded to encompass not only survivors of Nazi persecution, but also witnesses to such violence. Some of these 'witnesses' belonged to the German and Austrian majority population, and their 'witnessing' occurred in close proximity to violence, in which they did not intervene on the part of the victims and to which they contributed in different ways. Zeitzeugen interview excerpts are a common sight in documentaries, especially those produced by the ZDF. Kansteiner argues that they suggest that the sensible way to behave is for the average morally sound citizen not to offer resistance and to keep their thoughts to themselves, and later bear witness. ${ }^{74}$ The figure of the Zeitzeuge has been promoted primarily through historical documentaries, but also in secondary education. Its impact on the ways in which individuals - both those acting as Zeitzeugen and those who do not, but belong to the same generation-has yet to be fully explored. The widespread familiarity with Zeitzeugen places interviewees in filmed interviews about the Nazi past into this wider context and the subject position of the Zeitzeuge. 
K.R.'s self-representation highlights the intertwining and reciprocal relationship between private narratives and public sphere. Here, the Zeitzeuge discourse and indeed practice affects how K.R. represents and sees himself, giving him the confidence to relate this story from a 'safe' and morally neutral subject position. Interviewers too help constitute this role as they use it, inadvertently or strategically, to build trust and rapport and position their interlocutors within a by now well-known trope, thus eliciting a certain type of narrative, as the contemporary witness seeks to live up to and fulfil this role. Holland utilizes this strategy at the outset or in relevant places in many interviews, explicitly calling his interlocutors Zeitzeugen, thus framing and situating them within a familiar discourse. The Zeitzeuge discourse - its ubiquity, impact, and uses on the side of both interviewer and intervieweeforms a key culturally and socially shared assumption underlying such encounters in the recent past. ${ }^{75}$ These assumptions or discourses shape encounters and the types of knowledge and subject positions that they produce.

\section{Conclusion}

If interviews conducted by historians or sociologists pose methodological and epistemological challenges, audio-visual accounts created by filmmakers face particular scrutiny and potentially dismissal as sources outside the confines of media history, film or cultural studies. Their particularity-economic considerations, the need to perform for and appeal to particular audiences, filmmaker persona, interviewing techniques that are informed more strongly by journalistic and entertainment imperatives than the established canon of oral history methods or against the background of historical knowledge and research questionsmake them circumspect as sources for historians. Where they are available, especially in unedited form, they have much to offer, however, and are less dissimilar to more traditional oral history than is often acknowledged, given their historical, socio-political, and cultural 
embeddedness. All audio-visual accounts are the result of the interaction and the negotiation between a narrator and the interviewer, and any imagined or actual future audience.

The approach, which I outlined here, makes for a fuller understanding of interviewers and a diverse range of interviewees, and the world that they inhabit, than the aforementioned event or meaning-focussed lines of enquiry. It considers the self and self-interest as socially and culturally situated, contingent, and relational and takes into account the narrators' attempt to maintain ego-integrity, to be able to think of themselves as good people. It highlights the limitations of vivid accounts and the possibilities incoherent narratives can offer, and the challenges of corroboration especially of interviews with relatively lowly actors. Arguably, this approach tells us less about the period 1933-45, and more about the context of the interaction. This is valuable to make sense of the post-war reverberations of Nazi violence, and indeed the legacy of the very processes of 'coming to terms' with the Nazi past. In addition, such accounts can further our understanding of grassroots involvement in everyday as well as more extreme forms of violence, the evaluation of such involvement later on, and how re-evaluations are interlinked with wider socio-political processes. They can provide an impetus for further research, especially for local and other microhistories, but cannot remain the sole source.

I have argued that in engaging with these sources, we can identify socially and culturally shared assumptions: a rise in anxiety in approaching Germans and Austrians on the side of persecutors, however widely or narrowly defined, and the figure of the contemporary witness or Zeitzeuge as practice, performance, discursive strategy, and subject position. This, in turn, indicates substantial shifts in value systems and public understandings — on the side of both interviewees and interviewers-, and in the ways in which individuals appropriate and assimilate them at different stages of their lives and in different contexts. As sites of negotiation, tension, and struggle over recognition of moral and epistemic authority, these accounts raise wider questions about interviewers and institutions creating, and later audiences 
engaging with them, particularly with regard to the knowledge and subjects such encounters

produce.

The research underpinning this article is funded by the Arts and Humanities Research Council (AHRC) as part of the project Compromised Identities? Reflections on Perpetration and Complicity under Nazism at UCL's Institute of Advanced Studies (IAS). I would to thank the anonymous reviewers for their comments on an earlier version of this article.

${ }^{1}$ Lawrence Langer, “The Missing Voices of the Killers: What Could They Tell US?”, Elements of Time (nd): 306310.

${ }^{2}$ Key accessible archives and collections include the "Perpetrators, Collaborators, and Witnesses: The Jeff and Toby Herr Testimony Initiative" at United States Holocaust Memorial Museum (USHMM); Yahad-In Unum; the Institute for History and Biography at FernUniversität Hagen; the Oral History Archive at Graz University; the Shoah Outtakes at USHMM; 'Projekt Menschenleben' at Österreichische Mediathek. Other interviews, such as those conducted by filmmaker Ruth Beckermann, journalist Gitta Sereny, or scholars like Gabriele Rosenthal, Harald Welzer, and Eric Johnson and Karl-Heinz-Reuband, along with many other smaller-scale research projects, are as of yet not available for "secondary research".

${ }^{3}$ Christopher B. Browning, Collected Memories: Holocaust History and Postwar Testimony (Madison and London: University of Wisconsin Press, 2003), 11-12.

${ }^{4}$ In her monograph Entnazifizierungsgeschichten: Die Auseinandersetzung mit der eigenen NS-Vergangenheit in der frühen Nachkriegszeit (Göttingen: Wallstein Verlag, 2020), Hanne Leßau skilfully analyses the 'denazification stories' through which Germans constructed an interpretation of the past that they could live with and that was palatable for the new West German democracy, thus demonstrating innovative uses of these sources for historical research.

${ }^{5}$ Mary Fulbrook and Ulinka Rublack, "In Relation: The 'Social Self' and Ego-Documents," German History 28, no. 3 (2010): 264-265.

${ }^{6}$ See e.g. Lee Ann Fuji, Killing Neighbors: Webs of Violence in Rwanda (Ithaca and London: Cornell University Press, 2009); Kieran Mitton, Rebels in a Rotten State: Understanding Atrocity in the Sierra Leone Civil War (London: Hurst/Oxford University Press, 2015); Kjell Anderson, Perpetrating Genocide: A Criminological Account (Abingdon: Routledge, 2018).

${ }^{7}$ See e.g. Erin Jessee, "The Limits of Oral History: Ethics and Methodology Amid Highly Politicized Research Settings," The Oral History Review 38, no. 2 (2011): 287-307; Kathleen M. Bee, "Methods, Interpretations, and Ethics in the Study of White Supremacist Perpetrators," Conflict \& Society: Advances in Research 1, no. 1 (2015): 9-22; (forthcoming) Kjell Anderson and Erin Jessee (eds), Researching Perpetrators of Genocide (Madison: University of Wisconsin Press, 2020).

${ }^{8}$ For the first type, see e.g. Christopher B. Browning, Ordinary Men: Reserve Police Battalion 101 and the Final Solution in Poland [1992] (London: Penguin, 2001); --, Collected Memories; Eric A. Johnson and Karl-Heinz Reuband, What We Knew: Terror, Mass Murder, and Everyday Life in Nazi Germany: An Oral History (Cambridge, MA: Basic Books, 2005). For the second type, see e.g. Lutz Niethammer, ed., "Die Jahre weiss man nicht, wo man die heute hinsetzen soll." Faschismus-Erfahrungen im Ruhrgebiet. Lebensgeschichte und Sozialkultur im Ruhrgebiet, Vol. I (Berlin-Bonn: Dietz, 1983); Dorothee Wierling, "Zeitgeschichte ohne Zeitzeugen: vom kommunikativen zum kulturellen Gedächtnis - drei Geschichten und zwölf Thesen," BIOS 21, no. 1 (2008): 28-36; Dan Bar-On, Legacy of Silence: Encounters with Children of the Third Reich (Cambridge: CUP, 1989); Harald Welzer, Sabine Moller, and Karoline Tschuggnall, 'Opa war kein Nazi': Nationalsozialismus und Holocaust im Familiengedächtnis (Frankfurt am Main: Fischer, 2002); Gabriele Rosenthal, '... Wenn alles in Scherben fällt...': Von Leben und Sinnwelt der Kriegsgeneration. Typen biographischer Wandlungen (Opladen: Leske + Budrich, 1987).

${ }^{9}$ See esp. the Institute for History and Biography at FernUniversität Hagen.

${ }^{10}$ See e.g. Franka Maubach, "Freie Erinnerung und mitlaufende Quellenkritik: zur Ambivalenz der Interviewmethoden in der westdeutschen Oral History um 1980," BIOS 26, no. 1 (2013): 28-52; See Linde Apel, "Oral History reloaded: Zur Zweitauswertung von mündlichen Quellen," Westfälische Forschungen 65 (2015):

243-254; Brigitte Halbmayr, "Sekundaeranalyse qualitativer Daten aus lebensgeschichtlichen Interviews:

Reflexionen zu einigen zentralen Herausforderungen," BIOS 21, no. 2 (2008): 256-267; Almut Leh,

"Forschungsethische Probleme in der Zeitzeugenforschung," BIOS 13, no. 1 (2000): 64-76. 
${ }^{11}$ Lawrence L. Langer, Holocaust Testimonies: the ruins of memory (New Haven: Yale University Press, 1991); Annette Wieviorka, The Era of the Witness, translated by Jared Stark (Ithaca, NY: Cornell University Press, 2016); Mark Roseman, The Past in Hiding (London: Penguin, 2000); Jan Taubitz, Holocaust Oral History und das lange Ende der Zeitzeugenschaft (Göttingen: Wallstein Verlag, 2016).

${ }^{12}$ According to Erikson, each stage of development in life is marked by the resolution of specific crises, resulting in particular strengths or pathologies. In the case of old age, this crisis is of "Integrity vs despair," which can lead to "wisdom' or "disdain." Erik H. Erikson, The Life Cycle Completed. Extended Version with New Chapters on the Ninth Stage of Development by Joan M. Erikson (New York and London: W.W. Norton \& Company, 1997); Richard Stevens, Erik Erikson: Explorer of Identity and the Life Cycle (Basingstoke: Palgrave Macmillan, 2008).

${ }^{13}$ Gabriele Rosenthal, "Erzählbarkeit, biographische Notwendigkeit und soziale Funktion von

Kriegserzählungen. Zur Frage: Was wird gerne und leicht erzählt,” BIOS, Sonderheft (1993): 5-24; Rosenthal, "... Wenn alles in Scherben fällt..."

${ }^{14}$ For a critique of this approach, see Melvin J. Lerner and Susan Clayton, Justice and Self-Interest: Two Fundamental Motives (Cambridge: CUP, 2011). See also Paul Bloomfield, Morality and Self-Interest (Oxford: OUP, 2007).

15 Jovan Byford, "Testimony," in Research methods for memory studies, ed. Emily Keightly and Michael Pickering (Edinburgh: Edinburgh University Press, 2013), 202; 208; See also Cristian Tileaga on reactions to confessions of former informants for the secret police in Romania, Cristian Tileaga, "The right measure of guilt: Moral reasoning, transgression and the social construction of moral meanings," Discourse \& Communication 6 , no. 2 (2012): 203-222.

${ }^{16}$ Byford, “Testimony,” 209. See also Jovan Byford and Cristian Tileaga, “Accounts of a Troubled Past: Psychology, History, and Texts of Experience,” Qualitative Psychology 4, no. 1 (2017): 101-117.

${ }^{17}$ I will discuss these issues at length in a monograph, provisionally titled Probing the German Mind, that will explore different, though at times overlapping, periods (c. 1944 to the present) with distinct modes of engagement with a "compromised past," in encounters and contexts which put "legitimising pressure" on nonpersecuted Germans and Austrians and, more recently, their interviewers.

18 Alexander Freund, "'Confessing Animals": Towards a Longue Durée History of the Oral History Interview', The Oral History Review 41, no. 1 (2014): 1.

${ }^{19}$ Katherine Model, Documenting Denial: Atrocities, Perpetrators, and the Documentary Interview (Unpublished thesis, New York University, 2016), 112.

${ }^{20}$ Final Account: Third Reich Testimonies is an archival project initiated and directed by Luke Holland (ZEF Productions Ltd) in association with University College London (UCL), the Wiener Library, the Institute National de l'Audiovisuel (France) and Founding Partners, Pears Foundation. Ultimately, this archive will be available to researchers through a cooperation between the Institute National de l'Audiovisuel, the Wiener Library and UCL, with a yet to be confirmed opening date. Access to some of the interviews may be restricted for a period owing to issues around data protection, ethics, or relevance. At the time of writing, access to the interviews is restricted to select researchers at UCL. Archival collection at UCL henceforth referenced as Final Account: Third Reich Testimonies@UCL.

${ }^{21}$ Mary Fulbrook, Dissonant Lives: Generations and violence through the German dictatorships (Oxford: OUP, 2011), 12 .

${ }^{22}$ Robert Knight, 'Drawing And Blurring the Lines after National Socialism: Austria and West Germany Compared', The Sixth Martin Miller and Hannah Norbert-Miller Memorial Lecture, Research Centre for German \& Austrian Exile Studies Institute of Modern Languages Research School of Advanced Study, University of London (London: Institute of Modern Languages Research, an imprint of the University of London Press, 2020), 13. Based on interviews with Austrian visitors to the Wehrmacht exhibition in the mid1990s, Hannes Heer distinguishes between three generations - "Landser" (1915-1924), recruits and young soldiers (1925-1929), and "Kriegskinder" (1930-1935)—who confronted the Nazi past in different ways. Women are not specifically considered in this concept of generations in the Austrian context, nor are the different trajectories of Austrian history. See Hannes Heer, Vom Verschwinden der Taeter: Der Vernichtungskrieg fand statt, aber keiner war dabei (Berlin: Aufbau-Verlag, 2004), 202-237.

${ }^{23}$ K.H. (134M) interviewed by Luke Holland on 17 November 2011; 25 June 2012; 1 July 2012, Final Account: Third Reich Testimonies@UCL.

${ }^{24}$ P.S. (040M) interviewed by Cornelia Reetz on 19 July 2010, Final Account: Third Reich Testimonies@UCL.

${ }^{25}$ H.Wn. (197M) interviewed by Luke Holland on 26 November 2012, Final Account: Third Reich

Testimonies@UCL.

${ }^{26}$ Jan Kiepe, Das Reservebattalion 101 vor Gericht: NS-Täter in Selbst- und Fremddarstellungen (Hamburg: LIT, 2007), 97.

${ }^{27}$ Stefan Kühl, Ganz normale Organisationen: Zur Soziologie des Holocaust (Berlin: Suhrkamp, 2014).

${ }^{28}$ Waitman W. Beorn notes that this was not a "successful legal strategy" at the Nuremberg Hostage Case as the tribunal "dismissed categorically any legality of German reprisal killings." Waitman W. Beorn, "A Calculus of 
Complicity: The Wehrmacht, the Anti-Partisan War, and the Final Solution in White Russia, 1941-42," Central European History 44, no. 2 (2011): 336.

${ }^{29}$ 1995-1999: War of Annihilation: Crimes of the Wehrmacht 1941 to 1944. Revised version 2001-2004:

Crimes of the German Wehrmacht: Dimensions of a War of Annihilation 1941-1944.

${ }^{30}$ H.La., N.La. (219FM) interviewed by Luke Holland on 12 August 2013. Final Account: Third Reich

Testimonies@UCL.

${ }^{31}$ Staatsarchiv Hamburg, 241-2 A 1980.

32 Dr Falk died in November 1939 in France, where he had stayed with his son. His daughter emigrated to Sydney, but his son was arrested by the Gestapo in the south of France in March 1944, and via Drancy deported to Auschwitz, where he was murdered in May 1944.

${ }^{33}$ Staatsarchiv Hamburg, A 452/0151; 241-1 I 1587; 241-2 A 3184.

${ }^{34}$ See e.g. Wendy Lower's interviews for USHMM, Germany Documentation Project.

${ }^{35}$ Sue Vice highlights this aspect in relation to Lanzmann's interviews with two former members of the Einsatzgruppen in the Shoah Outtakes. Sue Vice, "Claude Lanzmann's Einsatzgruppen Interviews," Holocaust Studies: A Journal of Culture and History 17, nos. 2-3 (2011): 70. For an impression of the mise-en-scène in Holland's interviews, see nine short films using excerpts from Final Account: Third Reich Testimonies@UCL under "Individual Responses to a Nazi Past" and "Involvement and Self-Representation" on https://compromised-identities.org/film-collection/.

${ }^{36}$ Holland shot additional footage of himself recording his journey but these recordings are not part of Final Account: Third Reich Testimonies@UCL.

37 Vice, "Claude Lanzmann's Einsatzgruppen Interviews."

${ }^{38}$ Model, Documenting Denial, 21.

${ }^{39}$ Ben Highmore, Cultural Feelings: Mood, Mediation and Cultural Politics (Abingdon and New York: Routledge, 2017), 2.

${ }^{40}$ Cf. USHMM, Oral history interview with Klaus D (2004), RG-50.486.0034; Österreichische Mediathek, Projekt MenschenLeben.

${ }^{41}$ Byford, "Testimony," 201.

${ }^{42}$ On oral history and memory studies, see e.g. Alessandro Portelli, The Death of Luigi Trastulli and other Stories: Form and Meaning in Oral History (New York: State University of New York Press, 1991); Paula Hamilton and Linda Shopes, Oral history and public memories (Philadelphia, Pa.: Temple University Press, 2008); Emily Keightly and Michael Pickering (eds), Research methods for memory studies (Edinburgh: Edinburgh University Press, 2013).

${ }^{43}$ Byford, "Testimony," 201.

${ }^{44}$ Sybille Schmidt, "Perpetrators' Knowledge: What and How Can We Learn from Perpetrator Testimony?" Journal of Perpetrator Research 1, no. 1 (2017): 101.

${ }^{45}$ Ibid.: 94. By contrast, Miranda Fricker alerts us to "epistemic injustice," specifically to "testimonial injustice," whereby listeners are less likely to give credence to an account by a particular social or ethnic group due to prejudice. Miranda Fricker, Epistemic Injustice: Power and the Ethics of Knowing (Oxford: OUP, 2007), 4.

${ }^{46}$ Sumner B. Twiss, "Can a perpetrator write a testimonio? Moral Lessons from the Dark Side," Journal of Religious Ethics 38, no. 1 (2010): 5

${ }^{47}$ Dori Laub and Nanette C. Auerhahn, "Probing the Minds of Nazi Perpetrators: The Use of Defensive Screens

in Two Generations," International Journal of Psychoanalysis 101, no. 2 (2020): 362.

${ }^{48}$ Browning, Collected Memories, 21-22.

${ }^{49}$ Even in the case of Reserve Police Battalion 101, probably the most infamous and most-studied group of faceto-face killers, self-interest is not straightforward. See e.g. Kühl, Ganz normale Organisationen, and esp. Jan Kiepe's forensic unpacking of both pre-trial investigations and interrogations, and trial statements demonstrates that the vast majority of the former members of Reserve Police Battalion 101 did not need to fear prosecution, as the notion of the Holocaust as an "organisational crime" informed the investigation and prosecution efforts, and treated most of them as "witnesses", who had been minor cogs in the wheel, under orders from above. As a result, the focus was largely on those, who, as superiors, bore more responsibility, and others who could be shown to have used their own initiative. Kiepe, Das Reservebattalion 101 vor Gericht.

${ }^{50}$ W.P. (130M) interviewed by Luke Holland on 18 October 2011, Final Account: Third Reich Testimonies@UCL; W.P. (130M) interviewed by Luke Holland on 6 November 2013, Final Account: Third ReichTestimonies@UCL.

${ }^{51}$ The resulting corpus of protocols and reports compiled by intelligence officers has recently been explored in Sönke Neitzel and Harald Welzer, Soldaten. On Fighting, Killing and Dying. The Secret WWII Transcripts of German POWs (New York: Alfred A. Knopf, 2012); Felix Römer, Kameraden: die Wehrmacht von innen (München: Piper: 2012). 
${ }^{52}$ National Archives and Records Administration, Maryland (NARA), RG 165, Entry P 179B, Box 527, 16 June 1944, Room Conversation; 7 June 1944 Morale Questionnaire. I/O: Pvt Koch; Report on Interrogation 7 June 1944 by Capt. Elggren; 19 June 1944, Report by Lt. Schneider; 14 June 1944, Report of Interrogation by Lt. Abels and Youkstetter.

${ }^{53}$ On Austria, see e.g. Ernst Hanisch, "Von der Opfererzählung zum schnellen Moralisieren. Interpretationen des Nationalsozialismus in Österreich," Geschichte und Gesellschaft 31, no. 2 (2005): 255-265; Heidemarie Uhl, "Of Heroes and Victims: World War II in Austrian Memory," Austrian History Yearbook 42 (2011): 185200.

${ }^{54}$ Harald Welzer, Grandpa Wasn't a Nazi: The Holocaust in German Family Remembrance (American Jewish Committee, 2005).

${ }^{55}$ Michelle Mouton and Helena Pohlandt-McCormick, "Boundary Crossings: Oral History of Nazi Germany and Apartheid South Africa: A Comparative Perspective," History Workshop Journal 48, no. 1 (1999): 58. ${ }^{56}$ Roseman, A Past in Hiding, 476-477.

${ }^{57}$ H.Ro. (092M) interviewed by Luke Holland on 29 March 2011, Final Account: Third Reich Testimonies@UCL.

${ }^{58}$ Nicholas Chare, "Gesture in Shoah," Journal for Cultural Research 19, no. 1 (2015): 31.

${ }^{59}$ Model, Documenting Denial, 30.

${ }^{60}$ Mouton and Pohlandt-McCormick, "Boundary Crossings," 59-60.

${ }^{61}$ Maubach, "Freie Erinnerung und mitlaufende Quellenkritik," 46-47.

${ }^{62}$ Lutz Niethammer, "Was unterscheidet Oral History von anderen interview-gestützten sozialwissenschaftlichen Erhebungs- und Interpretationsverfahren?" BIOS 20, Sonderheft: Kritische Erfahrungsgeschichte und grenzüberschreitende Zusammenarbeit. The Networks of Oral History. Festschrift für Alexander von Plato, ed. Almut Leh and Lutz Niethammer (2007): 60-65.

${ }^{63}$ Maubach, "Freie Erinnerung und mitlaufende Quellenkritik," 42-44.

${ }^{64}$ K.R. (198M) interviewed by Luke Holland on 28 November 2012, Final Account: Third Reich Testimonies@UCL; K.R. (198M) interviewed by Luke Holland on 8 August 2013, Final Account: Third Reich Testimonies@UCL.

${ }^{65}$ The 2006 interview is featured on KanalB.AT, under the theme of "ZeitzeugInnen des NS-Regimes." The interview with K.R. was conducted in November 2006, and the portal features seven clips totalling around 45 minutes: The interview questions are edited out. Short summaries inform of the content of each excerpt. The massacre is part of "Aufenthalt in der Sowjetunion." https://kanalb.org/topic.php?play id=1537\&modul=Clip\&clipId=195

${ }^{66}$ Truman O. Anderson, "A Hungarian Vernichtungskrieg? Hungarian Troops and the Soviet Partisan War in Ukraine, 1942," Militärgeschichtliche Mitteilungen 58, no 2 (1999): 345-366.

${ }^{67}$ Already in 1941, Germans had killed Jews in Rovno and the Pinsk marshes. The SS-Cavalry Brigade killed Jews in the Pripyat marshes in the area of Army Group Center from August 1941. In September 1942, hundreds of Jews escaped into the marshes from the Łachwa Ghetto following an armed uprising when the ghetto was liquidated, but most of them were eventually tracked down and killed. SS and police units operating within the boundaries of Army Group South conducted reprisals of the sort K.R. describes during 1942 and 1943. The absence of men in K.R.'s story may place the massacre within the context of genocidal action against Jews; or point to an evacuation order given by deputy commander of Army Group South Lt. General Erich Friderici in September 1942, to evacuate i.e. deport adult males and dismantle the area between Seredyna-Buda and the Desna East of Hremiach. See Beorn, "A Calculus of Complicity," 321; BStU, MfS HA IX/11 RHE 20/69 T.6; MfS HA IX/11 RHE 20/69 T.8; Anderson, "A Hungarian Vernichtungskrieg."

${ }^{68}$ Bloomfield, Morality and Self-Interest, 302-304.

${ }^{69}$ Wulf Kansteiner, In pursuit of German memory: History, Television, and Politics after Auschwitz (Athens: Ohio University Press, 2016), 257.

${ }^{70}$ As Truman O. Anderson notes, in the area of Army Group South in 1942, "Hungarian units did in fact use severely brutal methods in the effort to crush partisan resistance in rear areas. [...] It seems that several of the most extreme reprisals which took place within Heeresgebiet Süd were perpetrated by Hungarian units." Anderson, "A Hungarian Vernichtungskrieg," 349.

${ }^{71}$ Erin McGlothlin, "Listening to the Perpetrators in Claude Lanzmann's 'Shoah'," Colloquia Germanica 43, no. 3 (2010): 245-248.

${ }^{72}$ See Beorn, "A Calculus of Complicity," 330.

${ }^{73}$ See in this context e.g. Christian Ernst and Peter Paul Schwarz, "Zeitzeugenschaft im Wandel:

Entwicklungslinien eines (zeit-)geschichtlichen Paradigmas in Kontexten von 'NS-Vergangenheitsbewältigung' und 'DDR-Aufarbeitung'," BIOS 25, no. 1 (2012): 27; Kansteiner, In pursuit of German memory; Martin Sabrow and Nobert Frei (eds), Die Geburt des Zeitzeugen nach 1945 (Göttingen: Wallstein Verlag, 2012). 
${ }^{74}$ Wulf Kansteiner, "Aufstieg und Abschied der NS-Zeitzeugen in den Geschichtsdokumentationen des ZDF," in Die Geburt des Zeitzeugen nach 1945, ed. Martin Sabrow and Nobert Frei (Göttingen: Wallstein Verlag, 2012), 340.

${ }^{75}$ We may find a precursor to or variant of this subject position in the positioning of perpetrators as experts, such as in the case of Franz Suchomel by Claude Lanzmann in Shoah: McGlothlin, "Listening to the Perpetrators." 